\title{
İş Sağlığı ve Güvenliğinde Yüz Yüze ve Uzaktan Eğitim Sistemlerinin Karşılaştırılması
}

\author{
Comparison of Face-to-face and Distance Education Systems in \\ Occupational Health and Safety
}

\author{
Hatice DALYAN (D) , Orkun DALYAN (D) , Ömer Faruk ÖZTÜRK (D) , Mehmet PişKiN
}

\begin{abstract}
ÖZET
Bu çalışmada, iş sağlığı ve güvenliği eğitimlerinde en etkili eğitim türünün tespiti amacıyla 60 beyaz yaka personelden oluşan gruba farklı zamanlarda yüz yüze ve uzaktan eğitim sistemleri uygulanmıştır. Araştırmada elde edilen verilerin istatistiksel analizinde Sosyal Bilimler için İstatistik Paketi 24.0 programından faydalanılmıştır. Katılımcıların 52'si (\%86.7) erkek, 33'ü (\%55) evlidir. Katılımcıların 31'i (\%51.7) 27-35 yaş aralığındadır. Katılımcıların sadece 15’i (\%25) lisansüstü düzeyde öğrenim durumuna sahiptir. Katılımcıların 39'u (\%65) 10 ylldan fazla mesleki tecrübeye sahiptir. Yüz yüze eğitimden elde edilen verilere göre, 36-45 yaș, lisans mezunu ve 1 yldan az mesleki tecrübeye sahip personellerin diğer gruplara göre yüz yüze eğitim sistemine daha olumlu cevaplar verdiği tespit edilmiştir. Uzaktan eğitimden elde edilen verilere göre, 45 yaș üzeri, ön lisans mezunu ve 10 ylldan fazla mesleki tecrübeye sahip personellerin diğer gruplara göre uzaktan eğitim sistemine daha olumlu cevaplar verdiği tespit edilmiştir. Uzaktan eğitim yönteminin yüz yüze eğitim yöntemine göre çok yüksek düzeyde etkili olduğu sonucuna ulaşılmıștır.

Anahtar Kelimeler: Covid-19, Çalışan davranışları, Uzaktan eğitim, Yüz yüze eğitim

\section{ABSTRACT}

In this study, face-to-face and distance education systems were applied to a group of 60 white-collar personnel at different times in order to determine the most effective education type in occupational health and safety education. Statistical Package for the Social Sciences 24.0 program was used in the statistical analysis of the data obtained in the study. 52 (86.7\%) of the participants were male and $33(55 \%)$ were married. $31(51.7 \%)$ of the participants are between the ages of $27-35$. Only $15(25 \%)$ of the participants have a graduate level education. 39 (65\%) of the participants have more than 10 years of professional experience. According to the data obtained from face-to-face education, it was determined that the personnel aged 36-45, undergraduate graduate and less than 1 year of professional experience gave more positive answers to the face-toface education system compared to other groups. According to the data obtained from distance education, it was determined that the personnel over the age of 45 , with an associate degree and more than 10 years of professional experience, gave more positive answers to the distance education system than the other groups. It was concluded that the distance education method is very effective compared to the face-to-face education method.

Keywords: Covid-19, Employee behavior, Distance education, Face to face education
\end{abstract}

Hatice DALYAN I haticedalyan8789@gmail.com

Çanakkale Onsekiz Mart Üniversitesi, Lisansüstü Eğitim Enstitüsü, Çanakkale, Türkiye

Çanakkale Onsekiz Mart University, Graduate School of Natural and Applied Sciences, Çanakkale, Turkey

Orkun DALYAN | orkundalyan@outlook.com

Çanakkale Onsekiz Mart Üniversitesi, Lisansüstü Eğitim Enstitüsü, Çanakkale, Türkiye

Çanakkale Onsekiz Mart University, Graduate School of Natural and Applied Sciences, Çanakkale, Turkey

Ömer Faruk ÖzTÜRK | ofozturk@comu.edu.tr

Çanakkale Onsekiz Mart Üniversitesi, Fen-Edebiyat Fakültesi, Çanakkale, Türkiye

Çanakkale Onsekiz Mart University, Faculty of Arts and Sciences, Çanakkale, Turkey

Mehmet PişKiN | mehmetpiskin@comu.edu.tr | Sorumlu Yazar/Corresponding Author Çanakkale Onsekiz Mart Üniversitesi, Teknik Bilimler Meslek Yüksek Okulu, Çanakkale, Türkiye Çanakkale Onsekiz Mart University, Vocational School of Technical Sciences, Çanakkale, Turkey 


\section{GİRIŞ}

Kültür, toplumların kendilerine özgü olan ve gelecek nesillere aktardıkları değerlerin bütünü olarak ifade edilebilir. Toplum kültürünün oluşumunda en temel etken ise eğitimdir [1]. Toplumların sosyal kültürü, okullardaki eğitim kültürü, işyerlerinde sağlık ve güvenlik kültürü eğitim yoluyla gelişmektedir [2]. Eğitim, bilginin vericiden alıcıya çeşitli şekillerde ulaştırılmasıdır. Tüm dünyada etkili olan SARS-CoV-2 (Covid-19) salgını ve teknolojinin hızla gelişmesi yüz yüze (geleneksel) eğitim yerine uzaktan (çevrimiçi) eğitimin tercih edilmesine sebep olmuştur. Gelişen teknolojiye paralel olarak uzaktan eğitimi kullanan kişi sayısı da her geçen gün artmaktadır. Uzaktan eğitim; öğretmen ve öğrencinin teknolojik araçlar ve farklı yöntemlerle mekândan ve zamandan bağımsız veya yarı bağımlı bir şekilde iletişim kurma şeklidir [3]. Öğretmen ve öğrencinin farklı mekanlarda bulunması sebebiyle çeşitli araçlar kullanılarak (internet, video, televizyon, bilgisayar, tablet vb.) bilginin aktarılması da diğer bir tanımdır [4]. Uzaktan eğitim sistemi son dönem de toplum tarafından bir kültür olarak benimsenmektedir.

Eğitim, iş sağlığı ve güvenliği (İSG) biliminde proaktif yaklaşım gereği yapılması gereken düzenleyici önleyici faaliyetlerin başında gelmektedir. Gelişen teknoloji ile işyerlerinde çalısanlara verilen İSG eğitimleri de uzaktan eğitim modeli ile verilmeye başlanmıştır. Covid-19 salgını nedeniyle evden çalışma sistemine dönülmesi İSG alanında uzaktan eğitim sistemini desteklemiştir [5]. Literatürde İSG alanında eğitim değerlendirmeleri ve uzaktan eğitim sistemi hakkında çeşitli araştırmalar mevcuttur.

Bryant ve Hartle (2000), Central Missouri State Üniversitesinde görevli personellere farklı türlerde verilen İSG mevzuatının belirttiği eğitimleri değerlendirmiştir. Araştırmada sınıf ortamında verilen eğitimlere ek olarak televiz- yon, video ve internet yöntemleri de kullanılmıştır. Araşıırma sonucunda çalşsanların zamanını daha elverişli yönetmesinden dolayı video destekli eğitimi tercih ettikleri raporlanmıştır [6].

Burke vd. (2006), çalşanların güvenlik bilgi düzeyi ve performansını arttıran aynı zamanda iş kazası, yaralanma ve meslek hastalıklarını azaltmayı hedefleyen farklı İSG eğitimleri üzerine araştırma yapmıştır. 1971-2003 yılları arasında konusu İSG eğitimleri olan akademik yayınları, meta-analiz yöntemini kullanarak derlemiştir. Araştırma sonucunda, uygulama ve birebir iletişim ağırlıklı İSG eğitimlerinin uzaktan eğitim yöntemlerine göre daha etkili olduğunu raporlamıştır [7].

Ho ve Dzeng (2010), Tayvan'da inşaat sektöründe çalışan personeller ile medya içerikli İSG eğitimlerinin öğrenme etkinliği ve personel memnuniyetine etkisini belirlemeye çalışııstır. Video, animasyon ve ders tekrarını içeren sistemler ile verilen İSG eğitimleri sonucunda personellerin güvenli davranışlar sergilediklerini raporlamıştır [8].

Yadigar (2010), uzaktan eğitim programlarının etkinliğini değerlendirmek amacıyla Gazi Üniversitesi bilişim sistemleri uzaktan eğitim tezsiz yüksek lisans programına devam eden 62 öğrenci ile 44 sorudan oluşan bir anket çalışması gerçekleştirmiştir. Araştırma sonucunda, öğrencilerin büyük çoğunluğunun uzaktan eğitim sistemini benimsediğini ve ileride yine uzaktan eğitim sistemine yöneleceklerini belirtmiştir. Ancak uzaktan eğitim sisteminin, öğrenme sürecine etkin katılım ve sorunlar karşısında yardım alabilme konularında yetersiz olduğunu ve geliştirilmesi gerektiği de raporlanmıştır [9].

Lee ve Lee (2015), Kore’deki göçmen çalışanlara verilen İSG eğitimlerinin uzaktan eğitim sistemi verilmesi ile memnuniyet derecelerini etkileyen faktörleri incelemiştir. 
Yaş, eğitim düzeyi, meslek türü ve cinsiyet değişkenleri ile anlamlı bir fark elde edememişken göçmenlerin milliyetleri ile anlamlı bir fark elde etmiştir. Ayrıca öğrenme ortamının öğrenme doyum derecesi üzerinde anlamlı bir farklıllğın olmadığını raporlamıştır. Araştırma sonucunda uzaktan eğitim sisteminin temelini oluşturan bağımsız öğrenme ortamını desteklemiştir [10].

Bahadırlığlu (2019), İnteraktif öğretme yöntemlerinin İSG'ye yönelik bilgi ve davranışa etkisi isimli çalışmasında, İzmir ilinde tekstil fabrikasında görevli 48 personeli iki gruba ayırarak, ilk gruba klasik yöntemde ikinci gruba ise interaktif yöntemde İSG eğitimleri vermiştir. Personellere eğitim öncesinde, eğitim sonrasında ve eğitimden bir ay sonra test uygulamıştır. Araştırma sonucunda, interaktif eğitim yönteminin klasik eğitim yöntemine göre pozitif yönde anlamlı farklılığı olduğunu tespit etmiştir [11].

Bayram (2020), İSG eğitimlerinin uzaktan eğitim sistemi ile verilmesi sonucunda katılımcıların uzaktan eğitim ile ilgili memnuniyetlerini incelemiştir. Sakarya Üniversitesinde akademik ve idari kadroda görev yapan personellere 2016 ve 2019 yıllarında uzaktan eğitim yöntemi ile eğitimler vermiş ve bu eğitimlere yönelik memnuniyet algılarını ölçmüştür. Çalışma sonucunda, akıcı üsluba sahip eğitmen ve görselliği arttırılmış olan eğitim materyallerine sahip 2019 yllında verilen eğitim memnuniyetinin 2016 yılında verilen eğitime göre istatistiki olarak yüksek olduğunu raporlamı̧şır [12].

Şimşek vd. (2020), bir üniversite hastanesinde görevli personellerin iş kazası bildirim sistemi, tıbbi atık güvenliği, çalışanların yükümlülükleri gibi konularda farkındalıklarını arttırmak üzere eğitim programı düzenlemiştir. Eğitim etkinliğini arttırmak için video tekniği kullanmıştır. İşsağlığı ve güvenliği bilgi düzeyi soru ortalamalarında eğitim sonrasında eğitim öncesine göre anlamlı farklılık tespit etmiştir. Uygulanan eğitimin materyali, içeriği ve süresinin geleneksel eğitim metodundan daha başarılı bulunduğunu raporlamıştır [13].

Yener Aydın ve Doğan (2020), Çalışanların İşs Sağlığı ve Güvenliği Eğitimlerinin Usul ve Esasları Hakkında yönetmelik doğrultusunda işyerlerinde çalışanlara verilen İSG eğitimlerinin çalışanlardaki algı düzeyini tespit etmeye çalışımışır. Araştırmada ilgili yönetmelikte yer alan eğitim konularını kullanarak 7 boyutlu yeni bir ölçek geliştirmişlerdir. Araştırma sonucunda çalışanların İSG eğitimlerine yönelik algılarının orta seviyede ve özel sektörde verilen İSG eğitimlerinin kamu sektöründe verilen İSG eğitimlerine göre daha yüksek algı seviyesinde olduğunu raporlamıştır [14].

Türkkan (2021), Başkent Üniversitesi’nde öğrenim gören 20 öğrenci ile grafik tasarım alanındaki yüz yüze ve uzaktan eğitim sistemlerinin öğrenciler üzerindeki etkilerini tespit etmeye çalışmıştır. Araştırma sonuçlarına göre, yüz yüze eğitim sisteminde öğrencilerin öğretim görevlileri ile birebir iletişim sağlamaları sonucunda motivasyon ve sosyalleşme durumlarının daha güçlü olduğu yönündedir. Ancak yüz yüze eğitim sisteminde katılamadıkları derse tekrar katılamama, ekonomik ve zaman bakımından daha zayıf olduğunu da raporlamışır. Uzaktan eğitimde, devam edilemeyen derslere tekrar ulaşım sağlanabilmesi sistemin güçlü özelliği olurken konsantrasyonun daha kısa sürede dağılması sistemin zayıf özelliği olduğunu raporlamıştır [15].

Uzaktan eğitim sistemi üzerine İSG alanını da kapsayan çeşitli araşıtırmalar bulunmasına rağmen çalışanların hangi eğitim sistemine daha yatkın olduğunun tespitini konu alan detaylı çalışmalar mevcut değildir. Bu sebeple İSG alanında çeşitli eğitim sistemlerinin karşılaşıtırılması ve çalı̧san profillerine göre daha etkili olan eğitim sisteminin 
tespit edilmesi önemlidir.

\section{YÖNTEM}

\section{A. Araştırmanın Amacı}

Bu çalışmanın amacı, İSG 'de yüz yüze ve uzaktan eğitim yöntemleri arasındaki farkllılıkların incelenmesidir.

Bu çalışma ile aşağıda yer alan sorulara cevaplar aranmaktadır:

- İşsağllğı ve güvenliği eğitimlerinde yüz yüze ve uzaktan eğitim sistemleri arasında hangi eğitim sistemi daha başarılıdır?

- Çalışanların demografik özellikleri dikkate alındığında yüz yüze eğitim sistemine hangi personeller daha yatkındır?

- Çalışanların demografik özellikleri dikkate alındığında uzaktan eğitim sistemine hangi personeller daha yatkındır?

Çalışma için 04/08/2021 tarih ve E-84026528050.01.04-2100129034 sayı ile Çanakkale Onsekiz Mart Üniversitesi Lisansüstü Eğitim Enstitüsü Etik Kurulu tarafından onay alınmıştır.

\section{B. Araştırma Yöntemi}

Bu çalışmada, seçili bir gruba farklı zamanlarda verilen yüz yüze ve uzaktan eğitimler öncesinde ve sonrasında yapılan sınav sonuçları değerlendirilmiştir. Araştırma evrenini Çanakkale ilinde inşaat sektöründe görevli beyaz yaka personeller ( $\mathrm{N}=75)$ oluşturmaktadır. Araştırmanın örneklemini \%95 güven düzeyine göre 60 personel oluşturmuştur [16]. Katılımcıların seçimi konusunda araştırmacının herhangi bir etkisinin olmaması ve rastlantısal bir seçim yapılabilmesi için olasılıklı örnekleme yöntemlerinden basit rastgele örnekleme yöntemi kullanılmışırı [17].

\section{Veri Toplama Araçları}

$\mathrm{Bu}$ çalışmada, katılımcıların özelliklerini tanımlayıcı türde (cinsiyet, medeni durum, yaş, öğrenim durumu ve mesleki tecrübe) 5 adet soru bulunan formlar oluşturulmuştur. Eğitimlerin öncesi ve sonrasında yapılan sınavların değerlendirilmesi için 20 'şer sorudan oluşan sınav soruları bulunmaktadır. Sınav soruları, inşaat sektöründe 10 yıldan fazla mesleki tecrübeye sahip 2 iş güvenliği uzmanı görüşü ile hazırlanmıştır. 20 personel ile pilot çalışma yapıldıktan sonra sınav soruları değerlendirilmiştir. Değerlendirme sonucunda sınav sorularında herhangi bir değişikliğe gerek olmadığı görülmüş ve pilot çalışma verileri de araştırmaya eklenmiştir. Genel araştırma hakkında bilgi verildikten sonra gönüllü oluru alınan personellere araştırma çalışması uygulanmışıtr. Yüz yüze eğitim süreci işyeri eğitim ofisinde birebir, uzaktan eğitim süreci ise eş zamanlı (senkron) olarak gerçekleştirilmiştir. Araştırmanın verileri 05.08.202105.10.2021 tarihleri arasında toplanmıştır.

\section{Veri Analizi}

Bu çalışmada, elde edilen verilerin analizi Sosyal Bilimler için İstatistik Paketi (SPSS) 24.0 ile yapılmıştır. Araştırmada kullanılan sınav sorularının Cronbach Alpha güvenirlik katsayısı, güvenilir bir değer olarak kabul edilen $\alpha=0,792$ olarak bulunmuştur. Sınav sorularının normallik dağılımları Kolmogorov-Smirnov testi ile analiz edilmiş ve dağılımların normal olduğu bulunmuştur. Ayrıca ölçümlerin varyanslarının homojenliği de levene testi ile incelenmiş ve varyansların homojen olduğu tespit edilmiştir. Veri setleri normal dağılım gösterdiğinden dolayı parametrik test grubunda yer alan analizler kullanılmıştır. Parametrik testlerden, iki seviyeli değişkeni olan ifadeler için Bağımsız Değişken t Testi (Independent Sample t Test), ikiden fazla seviyeli değişkeni olan ifadeler için Tek Yönlü Varyans Analizi (One-Way Anova) kullanılmıştır [18].

Eğitimler öncesi ve sonrası sınav ortalamaları arasındaki farklılı̆̆ın tespiti için Bağımlı Değişken t Testi (Paired Sample t Test) kullanılmışıır. Etki büyüklüğü analizinde 
ise Cohen d (d) etki büyüklüğü kat sayısı hesaplanmıştır. Cohen $\mathrm{d}$ etki büyüklüğü; $0,2<\mathrm{d}<0,5$ ise küçük (az), 0,5 $<\mathrm{d}<0,8$ ise orta, $0,8<\mathrm{d}<1$ ise büyük ve $1<\mathrm{d}$ ise çok büyük etki olarak yorumlanmıştır [19]. Araştırmaya katılan çalışanların demografik özellikleri ve sınav sorularına ilişkin bulgular frekans ve yüzde ölçüleri kullanılarak tablolar halinde sunulmuştur. Elde edilen bulgular \%95 güven aralı̆̆ında, \%5 anlamlılık düzeyinde değerlendirilmiştir [20].

$\mathrm{Bu}$ araştırma, Çanakkale ilinde faaliyet gösteren inşaat sektöründe görevli beyaz yaka personellerin görüşleri ile sınırlıdır. Bu nedenle araştırma verileri bu evren-örneklem özellikleri ile sınırlı olup genellemeler yapılırken bu sınırlama dikkate alınmalıdır.

\section{BULGULAR}

Araştırmaya katılan personellerin demografik özelliklerinin frekans (f) ve yüzde (\%) dağılımları Tablo 1'de verilmiştir.

Tablo 1: Araştırmaya katılan personellerin demografik özelliklerinin frekans ve yüzdeleri

\begin{tabular}{llcc}
\hline Demografik Özellikler & & $\mathbf{f}$ & $\%$ \\
\hline \multirow{2}{*}{ Cinsiyet } & Kadın & 8 & 13,3 \\
& Erkek & 52 & 86,7 \\
\hline Medeni Durum & Evli & 33 & 55,0 \\
& Bekâr & 27 & 45,0 \\
\hline \multirow{2}{*}{ Yaş } & $18-26$ yaş aralığı & 10 & 16,7 \\
& 27-35 yaş aralığı & 31 & 51,7 \\
& 36-45 yaş aralığı & 11 & 18,3 \\
& 45 yaş üzeri & 8 & 13,3 \\
\hline Öğrenim Durumu & Ön Lisans & 22 & 36,7 \\
& Lisans & 23 & 38,3 \\
& Lisansüstü & 15 & 25,0 \\
\hline Mesleki Tecrübe & 1 yıldan az & 5 & 8,3 \\
& $1-5$ yıl arası & 10 & 16,7 \\
& $5-10$ yıl arası & 65,0 \\
\hline
\end{tabular}

Tablo 1'e göre, katılımciların 8’i (\%13,3) kadın, 52'si $(\% 86,7)$ erkektir. Katılımcıların 33'ü $(\% 55,0)$ evli, 27’si $(\% 45,0)$ bekârdır. Katılımcıların 10’u (\%16,7) 18-26 yaş, 31'i (\%51,7) 27-35 yaş, 11'i (\%18,3) 36-45 yaş aralığındadır. Katılımcıların sadece 8’i $(\% 13,3) 45$ yaş üzerindedir. Katılımciların 22'si $(\% 36,7)$ ön lisans, 23’ü $(\% 38,3)$ lisans ve $15{ }^{\prime} \mathrm{i}(\% 25,0)$ lisansüstü düzeyde öğrenim durumuna sahiptir. Katılımciların 5’i $(\% 8,3) 1$ yıldan az, 10’u (\% $16,7)$ 1-5 yıl arası, 6'sı (\%10,0) 5-10 yil arası ve 39'u (\% 65,0) 10 yll üzeri mesleki tecrübeye sahiptir.

Personellerin sınav sorularına verdikleri cevapların cinsiyet ve medeni durum değişkenlerine göre bağımsız değişken t-testi sonuçları Tablo 2'de verilmiştir.

Tablo 2: Sınav ortalamaları arasındaki farklılı̆ğı cinsiyet ve medeni durum değişkenlerine göre bağımsız değişken

\begin{tabular}{|c|c|c|c|c|c|c|}
\hline & & $\mathbf{N}$ & $\overline{\mathbf{X}}$ & Sd & $t$ & $p$ \\
\hline \multirow{4}{*}{$\begin{array}{l}\text { Yüz yüze eğitim } \\
\text { fark puanları }\end{array}$} & Kadın & 8 & 15,00 & 7,07 & \multirow{2}{*}{,- 186} & \multirow{2}{*}{0,857} \\
\hline & Erkek & 52 & 15,48 & 4,77 & & \\
\hline & Evli & 33 & 16,36 & 5,48 & \multirow{2}{*}{1,623} & \multirow{2}{*}{0,110} \\
\hline & Bekâr & 27 & 14,25 & 4,31 & & \\
\hline \multirow{4}{*}{$\begin{array}{l}\text { Uzaktan eğitim } \\
\text { fark puanları }\end{array}$} & Kadın & 8 & 24,37 & 4,95 & \multirow{2}{*}{,- 212} & \multirow{2}{*}{0,833} \\
\hline & Erkek & 52 & 24,90 & 6,75 & & \\
\hline & Evli & 33 & 26,36 & 5,89 & \multirow{2}{*}{2,069} & \multirow{2}{*}{$0,043^{*}$} \\
\hline & Bekâr & 27 & 22,96 & 6,83 & & \\
\hline \multirow{4}{*}{$\begin{array}{l}\text { Eğitimler arası } \\
\text { fark puanları }\end{array}$} & Kadın & 8 & 9,37 & 8,21 & \multirow{2}{*}{,- 016} & \multirow{2}{*}{0,988} \\
\hline & Erkek & 52 & 9,42 & 8,02 & & \\
\hline & Evli & 33 & 10,0 & 8,10 & \multirow{2}{*}{623} & \multirow{2}{*}{0,536} \\
\hline & Bekâr & 27 & 8,70 & 7,91 & & \\
\hline
\end{tabular}

${ }^{*}=p<, 05, p=, 05, N=$ Katlımcı Sayısı, $\bar{X}=$ Ortalama, Sd= Standart Sapma

Tablo 2 incelendiğinde, kadın personellerin yüz yüze eğitim sınavları arasındaki fark puanların ortalaması $\overline{\mathrm{X}}_{\text {kadın }}=15,00$, erkek personellerin ortalamas $\bar{X}_{\text {erkek }}=15,48$ ' dir. Bağımsız değişken $\mathrm{t}$ testi sonuçlarına göre yüz yüze eğitim sonucunda kadın ile erkek personellerin test ortalamaları arasında istatistiksel olarak anlamlı fark tespit edilememiştir [ $t=-, 186, p>, 05]$. Evli personellerin yüz yüze eğitim sınavları arasındaki fark puanların ortala- 
ması $\quad \overline{\mathrm{X}}_{\text {evli }}=16,36$, bekâr personellerin ortalaması $\bar{X}_{\text {bekâr }}=14,25$ 'tir. Bağımsız değişken $\mathrm{t}$ testi sonuçlarına göre yüz yüze eğitim sonucunda evli ile bekâr personellerin test ortalamaları arasında istatistiksel olarak anlamlı fark tespit edilememiştir $[\mathrm{t}=1,623, \mathrm{p}>, 05]$.

Kadın personellerin uzaktan eğitim sınavları arasındaki fark puanların ortalaması $\overline{\mathrm{X}}_{\text {kadın }}=24,37$, erkek personellerin ortalaması $\bar{X}_{\text {erkek }}=24,90$ 'dır. Bağımsız değişken $t$ testi sonuçlarına göre uzaktan eğitim sonucunda kadın ile erkek personellerin test ortalamaları arasında istatistiksel olarak anlamlı fark tespit edilememiştir $[\mathrm{t}=-, 212, \mathrm{p}>, 05]$. Evli personellerin uzaktan eğitim sınavları arasındaki fark puanların ortalaması $\overline{\mathrm{X}}_{\text {evli }}=26,36$, bekâr personellerin ortalaması $\bar{X}_{\text {bekâr }}=22,96$ 'dır. Bağımsız değişken t testi sonuçlarına göre uzaktan eğitim sonucunda evli ile bekâr personeller arasında evli personeller lehine istatistiksel olarak anlamlı farklılık gözlemlenmiştir [ $\mathrm{t}=2,069, \mathrm{p}<, 05]$. Hesaplanan etki büyüklüğü Cohen's d katsayısına göre orta derece etkiye sahip olduğu söylenebilir $(\mathrm{d}=0,53)$.

Kadın personellerin eğitimler arasındaki fark puanların ortalaması $\bar{X}_{\text {kadin }}=9,37$, erkek personellerin ortalaması $\bar{X}_{\text {erkek }}=9,42$ 'dir. Bağımsız değişken t testi sonuçlarına göre kadın ile erkek personellerin test ortalamaları arasında istatistiksel olarak anlamlı fark tespit edilememiştir. [ $\mathrm{t}=-, 016$, $\mathrm{p}>, 05]$. Evli personellerin eğitimler arasındaki fark puanların ortalaması $\overline{\mathrm{X}}_{\mathrm{evli}}=10,0$, bekâr personellerin ortalaması $\bar{X}_{\text {bekâr }}=8,70$ 'tır. Bağımsız değişken $t$ testi sonuçlarına göre evli ile bekâr personellerin test ortalamaları arasında istatistiksel olarak anlamlı fark tespit edilememiştir $[t=, 623$, $\mathrm{p}>, 05]$.

Tablo 3'te personellerin sınav ortalamaları arasındaki fark puanların yaş, öğrenim durumu ve mesleki tecrübe değişkenlerine göre ortalama ve standart sapma sonuçları verilmiştir.
Tablo 3: Personellerin eğitim puanlarının yaş, öğrenim durumu ve mesleki tecrübe değişkenlerine göre ortalama ve standart sapma sonuçları

\begin{tabular}{|c|c|c|c|c|c|}
\hline & & & $\mathbf{N}$ & $\bar{x}$ & Sd \\
\hline \multirow{11}{*}{$\begin{array}{l}\text { Yüz yüze } \\
\text { eğitim } \\
\text { fark } \\
\text { puanları }\end{array}$} & \multirow{4}{*}{ Yaş } & $19-24$ arası & 10 & 14,50 & 3,68 \\
\hline & & $25-35$ arası & 31 & 15,32 & 5,31 \\
\hline & & $36-45$ arası & 11 & 16,81 & 5,13 \\
\hline & & 45 üzeri & 8 & 15,00 & 5,97 \\
\hline & \multirow{3}{*}{$\begin{array}{c}\text { Öğrenim } \\
\text { Durumu }\end{array}$} & Ön Lisans & 22 & 14,77 & 4,99 \\
\hline & & Lisans & 23 & 16,52 & 4,86 \\
\hline & & Lisansüstü & 15 & 14,66 & 5,49 \\
\hline & \multirow{4}{*}{$\begin{array}{l}\text { Mesleki } \\
\text { Tecrübe }\end{array}$} & 1 yıldan az & 5 & 16,00 & 6,51 \\
\hline & & $1-5 \mathrm{yıl}$ arası & 10 & 15,00 & 5,27 \\
\hline & & 5-10 yıl arası & 6 & 15,00 & 5,47 \\
\hline & & 10 yıldan fazla & 39 & 15,51 & 4,97 \\
\hline \multirow{11}{*}{$\begin{array}{l}\text { Uzaktan } \\
\text { eğitim } \\
\text { fark } \\
\text { puanları }\end{array}$} & \multirow{4}{*}{ Yaş } & $19-24$ arası & 10 & 24,00 & 6,99 \\
\hline & & $25-35$ arası & 31 & 25,48 & 6,50 \\
\hline & & $36-45$ arası & 11 & 21,81 & 4,04 \\
\hline & & 45 üzeri & 8 & 27,50 & 8,01 \\
\hline & \multirow{3}{*}{$\begin{array}{c}\text { Öğrenim } \\
\text { Durumu }\end{array}$} & Ön Lisans & 22 & 25,45 & 7,54 \\
\hline & & Lisans & 23 & 24,78 & 5,73 \\
\hline & & Lisansüstü & 15 & 24,00 & 6,32 \\
\hline & \multirow{4}{*}{$\begin{array}{l}\text { Mesleki } \\
\text { Tecrübe }\end{array}$} & 1 yıldan az & 5 & 25,00 & 5,00 \\
\hline & & $1-5 \mathrm{yıl}$ arası & 10 & 25,00 & 8,16 \\
\hline & & 5-10 yıl arası & 6 & 22,50 & 5,24 \\
\hline & & 10 yıldan fazla & 39 & 25,12 & 6,53 \\
\hline \multirow{11}{*}{$\begin{array}{c}\text { Eğitimler } \\
\text { arası fark } \\
\text { puanları }\end{array}$} & \multirow{4}{*}{ Yaş } & $19-24$ arası & 10 & 9,50 & 6,85 \\
\hline & & $25-35$ arası & 31 & 10,16 & 8,61 \\
\hline & & $36-45$ arası & 11 & 5,00 & 5,00 \\
\hline & & 45 üzeri & 8 & 12,50 & 8,86 \\
\hline & \multirow{3}{*}{$\begin{array}{l}\text { Öğrenim } \\
\text { Durumu }\end{array}$} & Ön Lisans & 22 & 10,68 & 8,20 \\
\hline & & Lisans & 23 & 8,26 & 8,20 \\
\hline & & Lisansüstü & 15 & 9,33 & 7,52 \\
\hline & \multirow{4}{*}{$\begin{array}{l}\text { Mesleki } \\
\text { Tecrübe }\end{array}$} & 1 yıldan az & 5 & 9,00 & 10,24 \\
\hline & & $1-5$ yıl arası & 10 & 10,00 & 7,45 \\
\hline & & $5-10$ yıl arası & 6 & 7,50 & 7,58 \\
\hline & & 10 yıldan fazla & 39 & 9,41 & 8,14 \\
\hline
\end{tabular}


Tablo 3 incelendiğinde; yüz yüze eğitim fark puanları yaş seviyeleri açısından en yüksek ortalamanın $36-45$ yaş arası grubunda $\overline{\mathrm{X}}=16,81$ ve en düşük ortalamanın ise 1924 yaş arası grubunda $\bar{X}=14,50$ olduğu, öğrenim durumu açısından en yüksek ortalamanın lisans mezunu $\bar{X}=16,52$ ve en düşük ortalamanın lisansüstü mezunu $\overline{\mathrm{X}}=14,66$ olduğu ve mesleki tecrübe açısından en yüksek ortalamanın 1 yıldan az $\bar{X}=16,00$ ve en düşük ortalamanın $1-5$ yıl arası ve 5-10 yıl arası $\bar{X}=15,00$ tecrübeye sahip olduğu görülmektedir.

Uzaktan eğitim fark puanları, yaş seviyeleri açısından en yüksek ortalamanın 45 yaş üzeri grubunda $\bar{X}=27,50$ ve en düşük ortalamanın ise $36-45$ yaş arası grubunda $\bar{X}=$ 21,81 olduğu, öğrenim durumu açıssndan en yüksek ortalamanın ön lisans mezunu $\overline{\mathrm{X}}=25,45$ ve en düşük ortalamanın lisansüstü mezunu $\overline{\mathrm{X}}=24,00$ olduğu ve mesleki tecrübe açısından en yüksek ortalamanın 10 yıldan fazla $\overline{\mathrm{X}}$ $=25,12$ ve en düşük ortalamanın 5-10 yıl arası $\bar{X}=22,50$ tecrübeye sahip olduğu görülmektedir.

Eğitimler arası fark puanlarında, yaş seviyeleri açısından en yüksek ortalamanın 45 yaş üzeri grubunda $\overline{\mathrm{X}}=12,50$ ve en düşük ortalamanın ise $36-45$ yaş arası grubunda $\bar{X}=$ 5,00 olduğu, öğrenim durumu açısından en yüksek ortalamanın ön lisans mezunu $\bar{X}=10,68$ ve en düşük ortalamanın lisans mezunu $\bar{X}=8,26$ olduğu ve mesleki tecrübe açısından en yüksek ortalamanın $1-5$ yıl arası $\bar{X}=10,00$ ve en düşük ortalamanın 5-10 yıl arası $\bar{X}=7,50$ tecrübeye sahip olduğu görülmektedir.

Personellerin, yaş, öğrenim durumu ve mesleki tecrübe değişkenlerine göre sınav ortalamaları arasındaki fark puanların ortalamalarını karşılaşııımak amacıyla yapılan tek yönlü varyans analizi (ANOVA) sonuçları Tablo 4'te verilmiştir.
Tablo 4: Personellerin yaş, öğrenim durumu ve mesleki tecrübe değişkenlerine göre ANOVA sonuçları

\begin{tabular}{|c|c|c|c|c|c|c|c|}
\hline & & VK & KT & Sd & ко & $\mathbf{F}$ & $\mathbf{p}$ \\
\hline \multirow{3}{*}{ 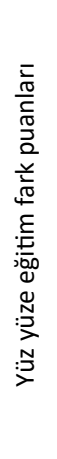 } & 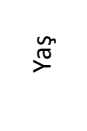 & GA & 31,673 & 56 & 10,558 & ,39 & ,754 \\
\hline & 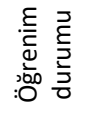 & GA & 1468,936 & 56 & $\begin{array}{l}22,824 \\
25,771\end{array}$ & ,88 & ,418 \\
\hline & 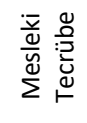 & GA & 1509,744 & 56 & 1,613 & ,06 & ,981 \\
\hline \multirow{3}{*}{ 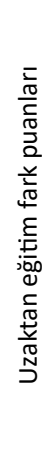 } & $\stackrel{m}{\infty}$ & GA & 2321,378 & 56 & 58,985 & 1,4 & ,246 \\
\hline & 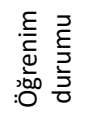 & GA & 2479,368 & 56 & $\begin{array}{c}9,483 \\
43,498\end{array}$ & ,21 & 805 \\
\hline & 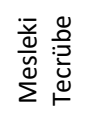 & $\begin{array}{l}\text { GA } \\
\text { Gi }\end{array}$ & 2461,859 & 56 & $\begin{array}{l}12,158 \\
43,962\end{array}$ & ,27 & 842 \\
\hline \multirow{3}{*}{ 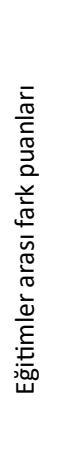 } & $\underset{m}{\infty}$ & GA & 3446,694 & 56 & 102,630 & 1,6 & 184 \\
\hline & 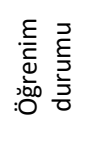 & GA & 3688,541 & 56 & 33,021 & ,51 & ,603 \\
\hline & 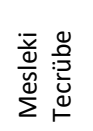 & GA & 27,853 & 56 & 9,284 & 14 & 936 \\
\hline
\end{tabular}

$\mathrm{VK}=$ Varyans kaynağı, KT=Kareler toplamı, KO=Kareler ortalaması, $\mathrm{GA}=$ Gruplar arası, $\mathrm{Gi}=$ Grup içi

Tablo 4 incelendiğinde, yaş, öğrenim durumu ve mesleki tecrübe değişkenlerine göre eğitimlerdeki fark puanları açııından istatistiksel düzeyde anlamlı bir farklılık yoktur.

Personellerin, eğitim türlerine göre bağımlı değişken t testi analizi sonuçları Tablo 5'te verilmiştir. 
Tablo 5: Personellerin eğitim türlerine göre bağımlı

\begin{tabular}{|c|c|c|c|c|c|c|c|}
\hline & & $\mathbf{N}$ & $\overline{\mathbf{x}}$ & Sd & $t$ & $p$ & d \\
\hline \multirow{2}{*}{ 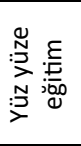 } & $\begin{array}{l}\text { Ön } \\
\text { Test }\end{array}$ & 60 & 52,58 & 10,63 & \multirow{2}{*}{$-23,56$} & \multirow{2}{*}{$0,000^{*}$} & \multirow{2}{*}{3,04} \\
\hline & $\begin{array}{l}\text { Son } \\
\text { Test }\end{array}$ & 60 & 68,00 & 12,59 & & & \\
\hline \multirow{2}{*}{ 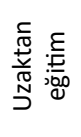 } & $\begin{array}{l}\text { Ön } \\
\text { Test }\end{array}$ & 60 & 55,08 & 8,61 & \multirow{2}{*}{$-29,56$} & \multirow{2}{*}{$0,000^{*}$} & \multirow{2}{*}{3,81} \\
\hline & $\begin{array}{l}\text { Son } \\
\text { Test }\end{array}$ & 60 & 79,91 & 7,83 & & & \\
\hline
\end{tabular}

*=p<,05, p=,05, d=Cohen $d$ etki büyüklüğü

Tablo 5 incelendiğinde, yüz yüze eğitimin ön test puan ortalaması $\overline{\mathrm{X}}=52,58$, son test puan ortalamas $\bar{X}=68,00$ 'dir. Bağımlı değişken $T$ testi sonuçlarına göre yüz yüze eğitimin ön test ile son test puan ortalamaları arasında son test lehine istatistiksel olarak anlamlı farklılık tespit edilmiştir $[\mathrm{t}=-23,56, \mathrm{p}<, 05]$. Hesaplanan etki büyüklügü Cohen $\mathrm{d}(\mathrm{d}=3,04)$ kat sayısına göre de bu farkl1lığın çok yüksek düzeyde etkili olduğu söylenebilir.

Uzaktan eğitimin ön test puan ortalaması $\bar{X}=55,08$, son test puan ortalaması $\overline{\mathrm{X}}=79,91$ 'dir. Bağımlı değişken T testi sonuçlarına göre uzaktan eğitimin ön test ile son test puan ortalamaları arasında son test lehine istatistiksel olarak anlamlı fark tespit edilmiştir $[\mathrm{t}=-29,56, \mathrm{p}<, 05]$. Hesaplanan etki büyüklüğü Cohen $\mathrm{d}(\mathrm{d}=3,81)$ kat sayısına göre de bu farklılığın çok yüksek düzeyde etkili olduğu söylenebilir.

\section{TARTIŞMA VE SONUÇ}

İş sağlığı ve güvenliğinde yüz yüze ve uzaktan eğitim yöntemleri arasındaki farklılıkların incelenmesi ve çalışan profiline uygun eğitim sisteminin tespiti amaciyla Çanakkale ilinde inşaat sektöründe görev yapan 60 beyaz yaka personel ile yapılan araştırma verileri Sosyal Bilimler için İstatistik Paketi (SPSS) 24.0 ile analiz edilmiştir.

Yüz yüze ve uzaktan eğitim yöntemleri ile uygulanan İSG eğitimlerinin her ikisinin de istatistiksel olarak anlamlı bir farklılık oluşturduğu tespit edilmiştir. Etki büyüklüğü analizleri incelendiğinde her iki eğitim grubunun da sınav fark puanları üzerinde yüksek derecede etkili olduğu ancak uzaktan eğitim modeli sınav fark puanlarının yüz yüze eğitim modeli sınav fark puanlarına göre daha yüksek derecede etkili olduğu tespit edilmiştir.

Yüz yüze eğitim ön test ve son test arasındaki fark puanları ile katılımcıların demografik özellikleri arasında anlamlı bir farklılık gözlenmemiştir. Uzaktan eğitim ön test ve son test arasındaki fark puanları ile sadece medeni durum değişkeninde evli personellerin lehine anlamlı bir farklılık gözlenmiştir. Ülkemizin Sakarya ilindeki Sakarya Üniversitesinde görev yapan personellere İSG eğitimlerinin uzaktan eğitim yöntemi verilmesi sonucu memnuniyetleri ölçülmüştür. Araştırma sonucunda, uzaktan eğitim sisteminin akademik personel memnuniyeti üzerinde anlamlı bir etkiye sahip olmasına rağmen idari personel üzerinde anlamlı bir etkiye sahip olmadığı bildirilmiştir. Araştırmacı, bu sonucun ortaya çımasında belirli bir zaman dilimi içinde belirli bir yerde eğitime katılma kısıtlaması bulunan çalışanların uzaktan eğitim sistemine yöneldiğini raporlamıştır [12]. Amerika Birleşik Devletlerinde Central Missouri State Üniversitesinde görevli personellere farklı türlerde verilen İSG eğitimlerinin değerlendirilmesi amacıyla bir araştırma çalışması gerçekleştirilmiştir. Araştırmada sınıf ortamında verilen eğitimlere ek olarak televizyon, video kaset ve internet kullanılarak sınıf ortamındaki etkileşimin arttırılması hedeflenmiştir. Araştırma sonucunda, üniversite personellerinin video kaset ile verilen eğitimleri daha çok tercih ettikleri raporlanmıştır. Araştırmacılar, bu sonucun ortaya çımasında personellerin zamanda esneklik ve elverişlilik sağlamasından dolayı video kaset yöntemine yöneldiklerini raporlamıştır [6]. Bu çalışmada evli olan çalışanların uzaktan eğitimi tercih etme sebebi, belirli bir zaman dilimi içinde belirli bir yerde eğitime katılma kısıtlamasından kaynaklanabilir. Uzaktan eğitim yönteminin evli olan 
personellere zaman konusunda daha fazla esneklik sağlaması uzaktan eğitimin tercihinde etkili olduğu söylenebilir.

Eğitim sistemlerine yatkınlık incelendiğinde; $36-45$ yaş, lisans mezunu ve 1 yıldan az mesleki tecrübeye sahip personellerin yüz yüze eğitime, evli, 45 yaş üzeri, ön lisans mezunu ve 10 yildan fazla mesleki tecrübeye sahip personellerin uzaktan eğitime daha olumlu yönde baktığı söylenebilir.

İlerleyen dönemde İSG eğitim süreçleri üzerine yapılacak araştırmalarda farklı eğitim modellerinin çalışan memnuniyetine ve iş tatminine etkisi üzerine çalışmalar yapılması önerilmektedir.

Yüz yüze ve uzaktan eğitim sistemlerine yatkın olan çalışan profillerinin tespiti, Cumhurbaşkanlığı 11. Kalkınma Planı 576. maddesinde belirtilen "İş sağlığı ve güvenliği alanında yürütülen hizmetlerin nitelik ve verimliliğinin arttırılmasına yönelik uygulamalar hayata geçirilecektir" hedefine ulaşılmasına katkı sağlayacağı ve gelecek dönemlerde yapılacak olan bilimsel çalışmalara ışık tutacağı düşünülmektedir.

YazAR KatKILARI: Yazarların katkıları eşit düzeydedir.

ÇıKaR ÇATışMASI: Yazarlar herhangi bir çıkar çatışması olmadığını, makalede araştırma ve yayın etiğine uyulduğunu beyan ederler.

Finansal Destek: Çalışmamıza Çanakkale Onsekiz Mart Üniversitesi Bilimsel Araştırma Projeler Birimi tarafından finansal destek sağlanmıştır (Proje numarası: FYL-20203180).

Етік Коміте Onayı: Çalışma için 03/08/2021 tarihinde E-84026528-050.01.04-2100129034 numarası ile Çanakkale Onsekiz Mart Üniversitesi Lisansüstü Eğitim Enstitüsü Etik Kurulu’ndan onay alınmıştır.

\section{KAYNAKÇA}

[1] Dalyan, O., Özkaya, N., Öztürk, Ö., \& Pişkin, M. (2021). Investigation and Comparison of Some Laboratories in Terms of Occupational Health and Safety by ELMERI Observation Method. Journal of Advanced Research in Natural and Applied Sciences, 7(2), 282-294.

[2] Dalyan, O., \& Pişkin, M. (2020). İşyerlerinde Ramak Kala Bildirimlerinin İş Kazalarına Etkisi ve İnşaat Sektöründe Uygulama. Çanakkale Onsekiz Mart Üniversitesi Fen Bilimleri Enstitüsü Dergisi, 6(1), 133-143.

[3] Koloğlu, T. F., Kantar, M., \& Doğan, M. (2016). Öğretim elemanlarının uzaktan eğitimde hazır bulunuşluklarının önemi. Açıköğretim Uygulamaları ve Araştırmaları Dergisi, 2(1), 52-70.

[4] Koçdar, S. (2006). Uzaktan eğitim ders kitaplarının geribildirim açısından değerlendirilmesi: Anadolu Üniversitesi'nin uzaktan eğitim veren İşletme ve İktisat Fakülteleri örneği, Yüksek Lisans Tezi, Anadolu Üniversitesi, Eskişehir.

[5] Mevzuatı Geliştirme ve Yayın Genel Müdürlüğü, Uzaktan Çalışma Yönetmeliği. Erişim Tarihi: 05.09.2021, Mevzuat Bilgi Sistemi

[6] Bryant, D. H., \& Hartle, J. A. (2000). Distance learning and occupational safety and health curriculum. Chemical Health \& Safety, 7(2), 34-36.

[7] Burke, M. J., Sue Ann Sarpy, S. A., Smith-Crowe, K., Chan-Serafin, S., Salvador, R. O., \& Islam, G. (2006). Relative Effectiveness of Worker Safety and Health Training Methods. American Journal of Public Health, 96(2), 315-324.

[8] Ho, C-L., \& Dzeng, R-J. (2010). Construction safety training via e-Learning: Learning effectiveness and user satisfaction. Computers \& Education, 55(2), 858-867.

[9] Yadigar, G. (2010). Uzaktan Eğitim Programlarının Etkinliliğinin Değerlendirilmesi (G.Ü. Bilişim Sistemleri Uzaktan Eğitim Tezsiz Yüksek Lisans Programı Örneği), Yüksek Lisans Tezi, Gazi Üniversitesi, Ankara.

[10] Lee, Y. J., \& Lee, D. (2015). Factors Influencing Learning Satisfaction of Migrant Workers in Korea with E-learning-Based Occupational Safety and Health Education. Safety and Health at Work, 6(3), 211 $-217$.

[11] Bahadırlığlu, M. (2019). İnteraktif öğretme yöntemlerinin iş sağlığı ve güvenliğine yönelik bilgi ve 
davranışa etkisi, Yüksek Lisans Tezi, İzmir Ekonomi Üniversitesi, İzmir.

[12] Bayram, M. (2020). Uzaktan İş Sağlığı ve Güvenliği Eğitim Kalitesinin Katılımcıların Memnuniyet Algılar1 Üzerinde Etkisi. The Journal of Social Science, 4 (7), 110-120.

[13] Şimşek, S., Öcek, A. Z., \& Türk, M. (2020). Bir Üniversite Hastanesinde Çalışanlara Uygulanan İşçi Sağlığı ve İş Güvenliği Eğitim Programının Etkinliğinin Değerlendirilmesi. Türkiye Halk Sağlığı Dergisi, 18(3), 183-194.

[14] Yener Aydın, B., \& Doğan, A. (2020). İş sağlığı ve güvenliği eğitimlerine yönelik çalışan algılarının belirlenmesi. Beykoz Akademi Dergisi, 8(2), 1-19.

[15] Türkkan, H. (2021). Yüz Yüze ve Uzaktan Eğitim ile Verilen Grafik Tasarım Proje Derslerinin Değerlendirilmesi. Sanat Dergisi, 37, 95-104.

[16] Krejcie, V. R., \& Morgan, W. D. (1970). Determining Sample Size for Research Activities. Educational and Psychological Measurement, 30, 607-610.

[17] Yıldız, S. (2011). Sosyal bilimlerde örnekleme sorunu: Nicel ve nitel paradigmalardan örnekleme kuramına bütüncül bir bakış. Kesit Akademi Dergisi, 3 (11), 421-442.

[18] Eymen, E. (2007). SPSS 15.0 Veri Analiz Yöntemleri. İstatistik Merkezi, Ankara.

[19] Kılıç, S. (2014). Etki büyüklüğü. Journal of Mood Disorders, 4(1), 44-46.

[20] Doğanay, A., Ataizi, M., Şimşek, A., Balaban Salı, J., \& Akbulut, Y. (2018). Sosyal Bilimlerde Araştırma Yöntemleri. Anadolu Üniversitesi Yayınları, Eskişehir. 